\title{
Technology and Pedagogic Trend of Education Process for Teachers in PGRI Organization
}

\author{
Muhammad Rusdil Fikri', Unifah Rosyidi², Siti Zulaikha3 \\ DOI: $10.35445 /$ alishlah.v13i2. 635
}

\begin{tabular}{l} 
Article Info \\
\hline Keywords: \\
Education; \\
Pedagogic; \\
PGRI Organization; \\
Technology
\end{tabular}

Kata kunci:

Pendidikan;

Pedagogik;

Organisasi PGRI;

Teknologi

\begin{abstract}
This study aims to determine the pedagogic concepts related to technology to implement the teacher education process in the PGRI (Persatuan Guru Republik Indonesia) organization. Pedagogy in the global era requires a combination of technology for teaching and learning activities. The research method is qualitative through descriptive evaluative. Data collection techniques consist of interviews, observation, and documentation. Data analysis techniques include the reduction process data, data presentation, drawing conclusions and triangulation. The results showed that the PGRI organization had six programs to improve pedagogic competence, namely training, seminars, building partnerships, developing learning media, optimizing subject teacher group associations, and building social awareness. Various programs provide many activities related to pedagogy and technology.
\end{abstract}

\begin{abstract}
Abstrak
Penelitian ini bertujuan untuk mengetahui konsep pedagogik yang terkait dengan teknologi untuk pelaksanaan proses Pendidikan para guru di organisasi PGRI (Persatuan Guru Republik Indonesia). Pedagogik di era global memerlukan perpaduan dengan teknologi untuk kegiatan pengajaran dan pembelajaran. Metode penelitian adalah kualitatif melalui deskriptif evaluative. Teknik pengumpulan data terdiri dari wawancara, observasi, dan documentation. Teknik analisis data antara lain proses reduksi data, penyajian data, penarikan simpulan, dan triangulasi. Hasil penelitian menunjukkan bahwa organisasi PGRI telah mempunyai enam program peningkatan kompetensi pedagogic yaitu pelatihan, seminar, membangun kemitraan, pengembangan media pembelajaran, mengoptimalkan asosiasi kelompok guru mata pelajaran, dan membangun kepedulian sosial. Berbagai program menyajikan banyak aktivitas yang terkait dengan pedagogik dan teknologi.
\end{abstract}

\footnotetext{
${ }^{1}$ Universitas Negeri Jakarta, Indonesia

Email: rusdilfikri@gmail.com

${ }^{2}$ Universitas Negeri Jakarta, Indonesia

Email: unifahr@gmail.com

3 Universitas Negeri Jakarta, Indonesia

Email: sitizulaikha@unj.ac.id
} 


\section{INTRODUCTION}

PGRI (Persatuan Guru Republik Indonesia) is a forum or organization for teachers throughout Indonesia that focuses on developing the quality of teachers. Especially in globalization, education in Indonesia is faced with various challenges due to various changes in science that continue to develop and increasingly advanced technology. It has provided a massive transformation of changes in the way people view humans, ways of looking at education, changes in the roles of parents, teachers, and lecturers, and changes in the pattern of relationships between them. One of the latent impacts of the rapid development of globalization is a change in the perspective of education itself. Various problems arise that impact the implementation of education that is not by the educational goals that have been proclaimed.

In addition, the teacher as an educator is required to know according to the changing times to produce qualified graduates. A graduate who can compete in the world. Therefore, the government has made various efforts to improve the quality and competence of teachers. One of the essential competencies is pedagogic competence. Advances in technology and science have changed the view of the pedagogic competence of teachers today. Teachers are not only able to teach in the classroom with lectures and manage the class conventionally. However, the digital era has changed conventional teaching patterns to be modern and authentic and limited time and content (MittonKükner \& Murray-Orr, 2018). The digital era demands are forcing the teacher to re-examine their professional identity in technology-integrated teaching (Avidov-Ungar \& Forkosh-Baruch, 2018; Backfisch et al., 2021). Thus, students also have abilities that are relevant to today's needs. Moreover, students also have technological devices that can be used as learning resources or media. So, technology is closely related to the pedagogic ability of teachers in carrying out teaching and learning activities in the classroom (Heitink et al., 2016).

The results of 100 teachers who are members of the PGRI organization conclude that around $60 \%$ of teachers experience many difficulties in designing learning in the digital era. Moreover, the COVID-19 pandemic conditions from 2020 have demanded teachers to use technology in implementing distance learning. Technology has to relate to the teacher's belief to succeed in learning (Heath \& Segal, 2021). However, many problems arise when pedagogic activities must be carried out with technological tools. Cultural and educational barriers hinder the adoption of technologies in educational practice (Wiziack \& dos Santos, 2021). So, the collaborative pedagogic approach is relevant to the current conditions (Garzón, Kinshuk, Baldiris, Gutiérrez, \& Pavón, 2020;DeLuca, Searle, Carbone, Ge, \& LaPointe-McEwan, 2021). It takes teacher competency improvement activities that lead to self-critical reflection as the implementing agent of educational institutions (Sanchez et al., 2018). Training is one way that can help improve pedagogical competence (Urban et al., 2018).

The previous study has presented teacher's pedagogic knowledge must be closely related to technological developments. This is the reason why this research is important. The reasons for the urgency to be considered are 1) understanding the context for teachers in implementing technology in teaching. It can be pedagogical creativity in achieving technological success (Zivitere et al., 2015). 2) The development of different pedagogical concepts for each teacher in various regions is challenging in the digital era. 3) Teacher needs related to pedagogical competency improvement programs in various regions.

Based on the reasons and studies of previous research, this study presents a solution to combining technology with the need to increase pedagogic competence to support quality teaching activities evenly distributed throughout Indonesia. Therefore, the research was conducted by involving teacher members in PGRI organizations in various parts of Indonesia. It is based on the assumption that each teacher has a different experience and institutional culture from each region in Indonesia. Thus, research can provide a fantastic orientation and contribution to the similarity of contexts in increasing pedagogic competencies relevant to the current digital era. The PGRI 
organization carries out various forms of programs in improving the quality of teacher pedagogic competencies. Programs can provide creativity and self-reflection (Liu \& Willis, 2021). So, this study aims to find trends in pedagogic competence in the educational process that are by current technological developments for teachers in the PGRI organization.

\section{METHODS}

The study used a qualitative approach by descriptive evaluative. Research that produces a suggestion, proposal or recommendation to the authorities to maintain, improve or dissolve the object under study based on the data found at the time of the research by narrating in the form of presentation. It illustrates the empirical reality behind the phenomena that occur related to the role of the PGRI organization in improving the pedagogic competence of teachers to face the digital era in Indonesia.

The participants involved in this study were teachers as members of the PGRI organization in Jakarta, West Java, Central Java, Lampung, and Central Sulawesi. Data collection techniques are through interviews. Interviews were aimed at teachers as members of the PGRI organization. Observations are carried out at PGRI offices in each region virtually and documentation. Process of analysis data used Miles and Huberman model (Miles \& Huberman, 1994) through the reduction process data, data presentation, drawing conclusions and triangulation.

\section{FINDINGS AND DISCUSSION}

The improvement of teacher pedagogic competence by PGRI is broadly grouped into six parts: training, seminars, building partnerships, developing learning media, optimizing subject teacher group associations, and building social awareness.

The first program is training. PGRI has carried out several activities to support teacher pedagogic competency training. The first activity is the PGRI literacy movement which is carried out to increase teachers' love for literacy so that their competencies are more relevant to current developments. The literacy movement that was launched required teachers to actively express creative ideas in written form and input them into online teacher magazines/media. The second activity is an online teacher who is to improve teacher competence, especially in personality competencies, so that later teachers in carrying out their duties can maintain their authority as an educator who should be used as an example. The third activity is writing, which is produced in the form of book publishing. The fourth activity is technical guidance to improve the competence of teachers related to their professional and pedagogic competencies.

The second program is seminars. PGRI improves teacher competence through various seminars. The seminars that have been carried out include: 1) Mindful Parenting and character habituation design in schools, 2) sharing knowledge with $3 \mathrm{~T}$ teachers, 3) evaluation and planning meetings, 4) RDP with Commission X DPR RI, and 5) PGRI digital literacy Wikiwebinar. The seminar conducted by PGRI online is due to the Covid-19 Pandemic and PPKM activities. Although the seminar activities are not face-to-face, the benefits impact teachers, especially in growing a scientific spirit and stimulating teachers' skills to speak and explore themselves.

The third program is to build strategic partnerships. In realizing various programs, PGRI builds cooperation with various government and private institutions. The partnerships that have been built consist of domestic partnerships and foreign partnerships. Domestic partnerships include; 1) Cooperating with the People's Consultative Assembly Republic Indonesia, 2) Cooperating with the Ministry of Education and Culture of the Republic of Indonesia, 3) Cooperating with PT Telekomunikasi Indonesia, 4) Cooperating with PT. Microsoft Indonesia, 5) Cooperating with the Indonesian Developers Association. As for PGRI's partnerships with institutions or organizations abroad, among others; 1) Education International Asia Pacific, and 2) Other international trusts. Building partnerships with various parties is carried out as PGRI's strategy in realizing its strategic programs considering that PGRI has limitations in terms of funding. Activities carried out in 
partnership with funding are usually borne jointly. As for the activities carried out by PGRI independently, the source of funding comes from the contributions of PGRI members collected through district/city PGRI administrators and Provincial PGRI. The resource persons in the activities carried out by PGRI came from PGRI management, the government, and partnership agencies.

The fourth program is the Development of Learning Media. PGRI carries out this program to modernize learning activities in the world of education. The resulting programs include; 1) PGRI Smart Learning and Character Center (SLCC), such as PGRI SLC E-Test, PGRI SLC E-Learning, PGRI LSC E-Library, and PGRI SLC E-Video, 2) Publication of scientific papers with various government or private institutions, and 3) Virtual Gurulympic Olympiad which encourages teachers to compete in developing learning media or innovations that are useful in learning activities in schools. The activities carried out in the Gurulympics are:

a. Cyber Pedagogy,

b. Gamification,

c. Online Evaluation,

d. Problem-Based learning,

e. Collaborative learning,

f. Learning Management System,

g. Flipped classroom,

h. Millennial Teachers,

i. Project-Based Learning

The fifth program is the Optimization of Subject Level Teacher Associations. PGRI carries out this program to improve the professional competence of teachers with a pattern of non-formal activities. The activities carried out are a) Association of Professionals and Similar Skills, b) Teacher Learning Circles, and c) Teacher Online Classes.

The sixth program is Building Teacher Social Awareness. Some of the activities carried out are a. Realizing Teacher Assistance Applications, b. PGRI Crisis Center Covid-19, and c. Building Strategic Partnerships. PGRI's efforts to improve teacher competence in the social aspect are carried out through fundraising among PGRI teachers throughout Indonesia to make donations to PGRI member teachers who are affected by disasters or disasters. Increasing teacher social competence is one of the efforts to build teacher emotional intelligence so that it can influence attitudes in interacting with the environment, especially the social aspects of society

The finding described developing pedagogic competence, which is quite good and by current needs. It means that various activities have been designed to meet the needs of teachers in improving the quality of teachers. These various activities fulfill the concept of seven aspects of pedagogy that must be mastered by teachers, namely the characteristics of educators, learning theories and teaching principles of learning, curriculum development, educational learning, developing the potential of students, ways of communicating, as well as assessment and evaluation of learning. These seven things can be obtained through the learning process of each teacher continuously and systematically.

PGRI, as the largest and oldest teacher struggle forum in Indonesia, assists teachers to realize their quality and be As an organization, PGRI already has completeness and a good organizational system. Therefore, improving the quality of teachers should be a priority to improve the quality of education. Education and training aim to increase the understanding and insight of teachers in carrying out learning activities for students. Of course, it also aims to increase the potential of each teacher. Meanwhile, seminars or webinars conducted by PGRI usually collaborate with several government agencies and private companies, including the Ministry of Education and Culture of the Republic of Indonesia, Microsoft, Telkom, and several other agencies that care about the development and improvement of education quality in Indonesia. Seminar activities are held at 
certain moments, such as national education day, national teacher's day, the birthday of PGRI and other important moments.

Various activities that the PGRI organization has designed have also led to the mastery of technology. We know that teachers' basic digital skills and technology-related teaching skills are more important than digital technology resources (Sailer et al., 2021). So far, teachers are still less effective in integrating technology in pedagogy. Schools can develop a technology integration framework to improve quality learning services (Salam et al., 2019). At present, the pedagogical competency framework must be understood to create graduates who are qualified and able to compete globally. They have to adapt the material in the curriculum as authentic (Davis et al., 2011). In higher education, Finland has used a knowledge system related to science for teacher education as a form of strategy that suits teacher education needs. Thus, teachers must understand pedagogical principles. One of them is teaching using relevant technology. The essence of good technology integration lies in recognizing the relationship between technology and pedagogy (Lin et al., 2015). The training that the PGRI organization has carried out has led to ways of connecting pedagogical knowledge and the use of technology in classroom teaching

Increasing competence is a professional demand and the development of science and technology today. In the global era, teachers are required to adapt, especially in teaching and learning activities in the classroom. Realizing the importance of increasing teacher competence, PGRI seeks to carry out various training activities to increase teacher pedagogic competence. Thus, teachers have competencies that are by government standards. In Government Regulation No. 19 of 2005 concerning National Education Standards in article 2 which contains that the standard of educators and teaching staff is one of the standards that must be met in national education, of course, demands the availability of educators with good quality. The more teachers have good competency standards, the better the quality they have.

In recent years, research reports have concluded that ICT integration is effective enough to meet teachers' needs to provide knowledge about technology, content, pedagogy, and this intersection, known as TPACK (Nordin et al., 2013; Koh \& Chai, 2016). It is known that ICT has the potential to improve the quality of education. However, the implementation of ICT is affected by structural transformation factors, teaching and learning, and technology in education (Sar \& Misra, 2020). Thus, the expansion of digital technology provides added value to improve quality teaching with collaboration (Blau et al., 2020). The 21st-century classroom calls for teachers to integrate technology into their learning practices. This requires the ability and willingness to combine technological, pedagogical and content knowledge (Kavanoz et al., 2015).

\section{CONCLUSION}

The improvement of teacher pedagogic competence is very diverse which has been adapted to technological developments. In this aspect, PGRI organizes various activities, such as educational training, seminars or webinars, developing learning media, optimizing subject teacher associations, building teacher social awareness, and building strategic partnerships. Obstacles faced in implementing teacher pedagogical competence improvement include; a) teacher and government trust in PGRI is still lacking, b) competency training is not commensurate with the number of teachers, and c) organizational, operational funding is limited. The solutions carried out are subtle diplomacy, digitizing organizations, and establishing strategic partnerships with various government and private agencies. Therefore, researchers who want to conduct further research on this theme must pay attention to these various obstacles. Research activities can be carried out by considering various problems that will be faced. Thus, these obstacles can become one of the focuses of research is integrated with the teacher's pedagogic competence. It means that the activities held can be in harmony with the context and literal understanding of pedagogics in the Law on Teachers and Lecturers Number 14 of 2015. 
The government must fully support the teacher improvement activities carried out by PGRI both at the central organization and regional PGRI management levels to strengthen the teacher professional organization in Indonesia. Meanwhile, PGRI management must seek; a) establishing better communication with all its partners to increase high trust in PGRI; b) the realization of synergy with the government for the realization of the PGRI program; c) maximizing teacher competency improvement programs in the regions so that the PGRI program can be implemented as a whole in the archipelago given the disproportionate number of teachers and PGRI abilities; d) PGRI needs to socialize the program to its members so that teachers are motivated to take part in teacher competency improvement activities.

\section{REFERENCES}

Avidov-Ungar, O., \& Forkosh-Baruch, A. (2018). Professional identity of teacher educators in the digital era in light of demands of pedagogical innovation. Teaching and Teacher Education, 73, 183-191. https://doi.org/10.1016/j.tate.2018.03.017

Backfisch, I., Scherer, R., Siddiq, F., Lachner, A., \& Scheiter, K. (2021). Teachers' technology use for teaching: Comparing two explanatory mechanisms. Teaching and Teacher Education, 104, 103390. https://doi.org/10.1016/j.tate.2021.103390

Blau, I., Shamir-Inbal, T., \& Avdiel, O. (2020). How does the pedagogical design of a technologyenhanced collaborative academic course promote digital literacies, self-regulation, and perceived learning of students? Internet and Higher Education, 45, 100722. https://doi.org/10.1016/j.iheduc.2019.100722

Davis, E. A., Beyer, C., Forbes, C. T., \& Stevens, S. (2011). Understanding pedagogical design capacity through teachers' narratives. Teaching and Teacher Education, 27(4), 797-810. https://doi.org/10.1016/j.tate.2011.01.005

DeLuca, C., Searle, M., Carbone, K., Ge, J., \& LaPointe-McEwan, D. (2021). Toward a pedagogy for slow and significant learning about assessment in teacher education. Teaching and Teacher Education, 101, 103316. https://doi.org/10.1016/j.tate.2021.103316

Garzón, J., Kinshuk, Baldiris, S., Gutiérrez, J., \& Pavón, J. (2020). How do pedagogical approaches affect the impact of augmented reality on education? A meta-analysis and research synthesis. In Educational Research Review (Vol. 31, p. 100334). Elsevier Ltd. https://doi.org/10.1016/j.edurev.2020.100334

Heath, M. K., \& Segal, P. (2021). What pre-service teacher technology integration conceals and reveals: "Colorblind" technology in schools. Computers and Education, 170, 104225. https://doi.org/10.1016/j.compedu.2021.104225

Heitink, M., Voogt, J., Verplanken, L., Van Braak, J., \& Fisser, P. (2016). Teachers' professional reasoning about their pedagogical use of technology. Computers and Education, 101, 70-83. https://doi.org/10.1016/j.compedu.2016.05.009

Kavanoz, S., Yüksel, H. G., \& Özcan, E. (2015). Pre-service teachers' self-efficacy perceptions on Web Pedagogical Content Knowledge. Computers and Education, 85, 94-101. https://doi.org/10.1016/j.compedu.2015.02.005

Koh, J. H. L., \& Chai, C. S. (2016). Seven design frames that teachers use when considering technological pedagogical content knowledge (TPACK). Computers and Education, 102, 244257. https://doi.org/10.1016/j.compedu.2016.09.003

Lin, C. C., Yu, W. W., Wang, J., \& Ho, M.-H. (2015). Faculty's Perceived Integration of Emerging Technologies and Pedagogical Knowledge in the Instructional Setting. Procedia - Social and Behavioral Sciences, 176, 854-860. https://doi.org/10.1016/j.sbspro.2015.01.550

Liu, T., \& Willis, K. (2021). Cut and paste pedagogy?: Academic mobility, teaching practices and the circulation of knowledge. Geoforum, 119, 11-20. https://doi.org/10.1016/j.geoforum.2020.12.025

Miles, M. B., \& Huberman, A. M. (1994). Qualitative Data Analysis; An Expanded Sourcebook. Sage Publication.

Mitton-Kükner, J., \& Murray-Orr, A. (2018). Pedagogies of pace: Temporal insights into Canadian pre-service teachers' pedagogical decision-making. International Journal of Educational Research, 9o, 32-42. https://doi.org/10.1016/j.ijer.2018.05.005

Nordin, H., Davis, N., \& Ariffin, T. F. T. (2013). A Case Study of Secondary Pre-service Teachers' Technological Pedagogical and Content Knowledge Mastery Level. Procedia - Social and 
Behavioral Sciences, 103, 1-9. https://doi.org/10.1016/j.sbspro.2013.10.300

Sailer, M., Murböck, J., \& Fischer, F. (2021). Digital learning in schools: What does it take beyond digital technology? Teaching and Teacher Education, 103, 103346. https://doi.org/10.1016/j.tate.2021.103346

Salam, M., Awang Iskandar, D. N., Ibrahim, D. H. A., \& Farooq, M. S. (2019). Technology integration in service-learning pedagogy: A holistic framework. Telematics and Informatics, 38, 257-273. https://doi.org/10.1016/j.tele.2019.02.002

Sanchez, H. S., Kuchah, K., Rodrigues, L., \& de Pietri, E. (2018). Pre-service language teachers' development of appropriate pedagogies: A transition from insightful critiques to educational insights. Teaching and Teacher Education, 70, 236-245. https://doi.org/10.1016/j.tate.2017.11.024

Sar, A., \& Misra, S. N. (2020). An empirical study to examine the components of technology-enabled distance education affecting students' perception. Materials Today: Proceedings. https://doi.org/10.1016/j.matpr.2020.10.781

Urban, E. R., Navarro, M., \& Borron, A. (2018). TPACK to GPACK? The examination of the technological pedagogical content knowledge framework as a model for global integration into college of agriculture classrooms. Teaching and Teacher Education, 73, 81-89. https://doi.org/10.1016/j.tate.2018.03.013

Wiziack, J. C., \& dos Santos, V. M. P. D. (2021). Evaluating an integrated cognitive competencies model to enhance teachers' application of technology in large-scale educational contexts. Heliyon, 7(1), e05928. https://doi.org/10.1016/j.heliyon.2021.e05928

Zivitere, M., Riashchenko, V., \& Markina, I. (2015). Teacher - Pedagogical Creativity and Developer Promoter. Procedia - Social and Behavioral Sciences, 174, 4068-4073. https://doi.org/10.1016/j.sbspro.2015.01.1156 